\title{
Students' Need on Creative Writing Based - Children Literature Course for EFL College Learners
}

\author{
Leni Marlina ${ }^{1}$ \\ Don Narius $^{2}$ \\ ${ }^{1}$ Corresponding author, Universitas Negeri Padang, Indonesia; lenimarlina@fbs.unp.ac.id \\ ${ }^{2}$ Universitas Negeri Padang, Indoensia; donnarius@fbs.unp.ac.id
}

\begin{abstract}
It is a big challenge to college language study programs in developing courses designed to equip students with the competencies that can be used to take part in the creative industries for instance creative writing. This research aims to find problems and to gather informasi needed to develop teaching-learning materials of creative writing based Children Literature course for EFL college students. This course is necessary to be developed in accordance to the need of creative writing as part of creative industry in responding the trend of world economy whish is lead to the creative industry. To develop teaching-learning materials of creative writing based Children Literature course effectively, the first research needed is to conduct students' need analysis by using questioner. This article describes (1) students' problems in understanding explanations of concepts and examples of Children Literature; (2) students' responses to the importance of various topics in the course of Children Literature; (3) students problems in learning subjects of Children Literature; (4) students' responses to the importance of diverse exercises and tasks in Children Literature; (5) students' responses to topics related to creative writing and Children Literature; (6) students' need to the media of learning creative writing-based Children Literature course.
\end{abstract}

Keywords: Children literature, Creative writing, Student's need analysis

\section{Introduction}

World universities must respond quickly and carefully trend of the world economy that increasingly leads to intellect and creativity based industries. One step that can be done is to develop courses designed to equip students with the competencies that can be used to take part in the creative industries world after completing the study period. This is important for the creative industry as a new economic sector that is believed to contribute significantly economy (Pangestu 2008:i). In this case, universities plays important role and they are also responsible for ensuring the relevance between subjects with the world of industry. 
In English Language Study Program, English Language and Literature Department of the Faculty of Language and Art, State University of Padang, there are a few of subjects that correspond to these objectives. One of them is Children Literature subject. This course is a compulsory subject with a weight of 2 credits. The main objective of this course is to introduce students to the English-language Children Literature. Meanwhile, the expected major competence controlled by the student in this course is the ability to appreciate works of Children Literature in English. In this case, students are required to think critically so as to convey the meaning that is behind the Children Literature based on the analysis of the content or context of the work to be appreciated.

This course is a course that is very important for the success of students in other subjects. First, the dominant learning experience in this course is to read literary texts in English. In other words, this will directly affect the language skills of reading (Reading) them. Second, the core competencies they have mastered making trained students to express their opinions based on the analysis. Thus, it will greatly help them in other subjects are also demanding analytical skills such as courses related to the study. Then, exposure to a variety of texts and genres of literary works can stimulate the creativity and the development of student ideas, and this has implications both for the course that is essentially the creation of such subjects writing.

Nonetheless, the potential possessed by this subject to the success of other subjects as well as relevance to the industrial world are invisible (intangible). In other words, students can not directly feel the benefits of competency they get with this course does not like courses that are skill or expertise. This is because the materials used during the main emphasis is to introduce students to the literary text and its benefits in academic and humane, while the benefits associated with the industrial world was not emphasized. Therefore, efforts are required to make the benefits of the courses in the industrialized world is felt directly by students (tangible). One of these efforts is the development of teaching materials for the course is designed to make students have competencies related to the world creative industry, in this case creative writing.

Based on the background above, this study is aimed to determine students' need on subject of 'Children Literature' of creative writing based teaching materials appropriate for students of English Language Study Program, Faculty of Languages and Arts, UNP.

\subsection{Literature Review}

\subsubsection{Children Literature}

Some authors argue that the Children Literature (Children Literature or Children Literature) is different from the adult literature (Lukens, 1995). Lesnik-Oberstein (1996) found that the word 'literature' when used in the context of 'Children Literature' can not be directly attributed to the word 'literature' as used in other contexts. Bottigheimer (1998: 190) argues that Children Literature is "an important system of its own". Many people consider that included in category of 'Children Literature', is quality work. For example, Hillman (1999: 3) which says that the writings were "conservative," "too predictable," or "too unreasonable" does not include Children Literature. Thus how does one determine whether a quality Children Literature that largely remains an open question. 
Tomlinson and Lynch-Brown (2002) proposed a set of evaluative criteria for determining the quality of Children Literature. The criteria relating to (a) fictitious elements (p. 22); (B) visual elements (p. 28); and (c) non-fictional elements (p. 170). This evaluative criteria described below.

\subsection{Elements of fiction}

a. Plot - A nice plot produce conflicts to build excitement and tension that can easily invite kids to get involved.

b. Character - the character to be remembered. The main character in a work of fiction that is very good for a child to develop fully, change in response to events that take lives.

c. The setting - the setting is an integral part of a story, which includes time and place. Although the setting is often not clear in the traditional literature for children, a detailed description of the settings can be an effective way to attract children.

d. Theme- themes in children's books should deserve the attention of children and must speak the truth to them. Furthermore, the theme should be based on moral and ethical standards are high. The theme does not have to beat the story plot and characters; Children read fiction for pleasure, not for enlightenment.

e. Style - the style is the way in which a writer to tell it. This is the aspect of the writing itself, as opposed to its contents. The style should be appropriate in relation to the content. Style elements include word choice, sentence selection and organization of the book. The words must be in accordance with the story told; sentence should be easy to read but the melody, and paragraphs, long chapters, titles and chapter titles, preface, endnotes, prologue, epilogue, and the length of the entire book should be designed with the age and developmental stage of the children.

What Tomlinson and Lynch-Brown said about the plot and characterization, although very common, it remains useless except insofar may not need or opportunity to enter, for example, a short story to allow the development of character. However, what they say about the setting, theme and style is less than helpful. For example, there may be a context in which the right not to provide details of specific measures do place settings. As far as the theme is concerned, to evaluate a book in terms of the extent to which attract the attention of children presupposes some prior knowledge about children's reactions to the work. Furthermore, children of cultural backgrounds and different languages may react very differently with a different theme. Moreover, it is unclear exactly what is meant by 'tell the truth'. Furthermore, although many adults now agree that the avoidance of explicit doctrine generally plausible, is highly dependent on the direction of the message. Children often prefer to apply the moral lesson to others as long as they see themselves as morally superior position.

\subsection{Visual elements}

a. Line - Lines are scratch marks that are part of the picture. Generally define a line drawing object in the image. Artists can choose to use a line of dark or pale, heavy or light, solid or broken, wide or thin, straight or curved, or have a combination of these elements. Line drawings will help create and convey meaning and feeling of the story.

b. Color - Color can be described in terms of hue, lightness, and saturation. Colors should be used to complement the text. For example, a soft warm tones associated with peace and satisfaction. Colors should be changed in accordance with the storyline. If the events and mood of the story changed during the story, then the color should be changed to reflect a shift in the story.

c. Forms - Forms evaluated for simplicity or complexity, definition or a lack of definition, rigidity or flexibility, and size. For example, negative or empty space can be used to highlight a particular object or to indicate isolation or loneliness. The shape of the image space surrounding the object shape and proportion in relation to one another is an important aspect of non-verbal 
messages.

d. Texture - Texture conveys an impression of how objects are drawn feel and can add a sense of reality to the illustration. Texture can be rough or slick, tight or chewy, hard or soft, serrated or smooth.

e. Composition - The composition includes the arrangement of visual elements in the image and how these visual elements relate to each other. Characteristics of the composition of the illustrations can help convey the overall sense of unity and to strengthen aspects of textual meaning.

What Tomlinson and Lynch-Brown said about the visual elements of children's books that are suggestive rather than truly informative. Nonetheless, it gives a useful starting point for those looking for a way to determine how, and why, children react in different ways with illustrations.

\subsection{Non-fiction}

a. Style; clear, straightforward, easy to understand is very important. Stylish devices such as the inclusion of questions including the second-person pronoun (you), such as "Have you ever wondered how chameleons change color?" Can stimulate the interest and involvement of the reader.

b. Description and labels must clearly written and informative. Although brief, this text serves an important piece to explain the importance of illustrations or draw the reader's attention to detail is important or interesting.

c. Facts must be accurate and current. Nonfiction must distinguish clearly between facts, theories, and opinions.

d. Personification should be avoided. Associate humans with animal characteristics, material objects, or natural force is part of the charm of traditional and modern works of fantasy. However, it should be avoided in non-fiction.

e. An interesting presentation. Non-fiction works must be packaged and presented attractively. Cover exciting, memorable illustrations, and the right balance between text and illustrations can make non-fiction more attractive to children.

f. Movement of known, unknown simple and common, more complex and specific. To help conceptual understanding and encourage analytical thinking, presentation of information should of known to unknown, general to specific, and simple to more complex.

g. Stereotypes should be avoided. Best non fiction beyond mere avoidance of sexist or racist language and stereotypical images in the text and illustrations. It also shows a positive image of cultural diversity.

h. Format and artistic media must be in accordance with its contents. Accuracy, clarity, and precision of photography, for example, makes this medium according to the authors whose purpose is to present the world as it is.

i. The depth and complexity of the subject of care should be appropriate for the intended audience. If an explanation should be simplified as far as the facts have to be changed before the child began to understand the concept or topic is not appropriate in terms of age and / or conceptual development of the intended audience

Tomlinson and Lynch-Brown refer to the 'style', claiming that Children Literature should be 'clear, direct and easy to understand'.

\section{Creative Writing and Creative Industry}

Creative writing is part of the world the creative industries. While the creative industry itself is an integral part of the creative economy (Ministry of Trade, 2008: i). In this case there are two terms that must be explained carefully, first, the creative economy, and, secondly, the creative industries. Creative economy 'focus on the creation of goods and services by relying on the expertise, talent and 
creativity as intellectual property (Ministry of Trade, 2008: 9). "Meanwhile Simatupang (2010: 1) states that the creative economy is a system of human activities related to the creation, production, distribution, exchange and consumption of goods and services, valuable cultural, artistic, aesthetic, intellectual, and emotional for the customers in the market. The main driving force of the creative economy is a human or creative people (Howkins, 2002, Florida, in 2005, and Lauter 2009).

Meanwhile, the creative industry is one of the things that is becoming an economic powerhouse creative. According to the United Kingdom Department of Culture, Media, and Sports (in Carr, 2009: 4), the creative industries are "Reviews those industries roomates have Reviews their origin in individual creativity, skill and talent, and the which have a potential for wealth and job creation to the generation and exploitation of intellectual property and content. Based on these definitions, we can say THAT creative industries is "derived from the utilization of industrial creativity, skills and individual talents to create wealth and jobs through the creation and use of creativity and inventiveness of the individual. One of the creative industries activity engendered by creative people are creative writing, the creative writing which includes fiction and non-fiction and other forms of literature. From the definition above, it is increasingly apparent that the industry actual creative is an economic activity that is truly relying on the intellect and creativity of individuals can prosper themselves or crowds.

In general, the fundamental differences between writing with a creative writing is speaking engagement creativity and imagination in creative writing. If writing is more closely related to the composition in the sense of writing for scientific purposes, then creative writing is closely associated with literature. Dawson (in Mansoor, 2010: 204) states that creative writing is a scientific field and a series of educational techniques. While Mansoor (2010: 206) defines creative writing as a form of writing that express thoughts and feelings of the author in a unique, imaginative, and poetic. Based on some of the above definition, it can be concluded that the creative writing at its core is an ability that can be learned and artistic expression by media language and involve imagination wherein the resulting product can be in the form of fiction, poetry, drama or creative writing other (movie script, advertisement script),

In this case, creative writing is one of the new fields than the field of composition that is not widely found references to the art pedagogy (Chong \& Lee, 2012: 639). Even if there are several references to the creative writing in the EFL context, the references to dwell on the attitudes and perceptions of students about creative writing in English and the benefits for the improvement of their English language skills (Dai, 2012; Chamchratsri, 2013; Kirmizi, 2015); in order to pedagogical and engineering, such as the manufacture of software that can be used to improve creative writing skills (Chong \& Lee, 2012); the mode of assessment (assessment) which can be used (Mozaffari, 2013). In essence, references to the learning model of creative writing in EFL contexts such as in Indonesia has not been found. But one thing is certain, according to Spatz (2012: 103) is a creative writing is a skill that can be taught (teachable).

However, for the purposes of this study, it should be great considering the study by Ansari et al (2012) in which they develop creative writing pedagogy in the form of an instructional approach based on the model taxonomic Moseley and Lenning. This study is based on two major camps in creative writing pedagogy, namely: (a) Socratic Constructivists is a group that does not believe in learning techniques such as learning instruction, the mechanism of learning strategies, or learning outcomes. The first group is believed that success in creative writing is highly dependent on thought or creativity of the writers themselves; (b) Isocratic Behaviourists are groups that believe that creativity is can be achieved by adherence to a set of learning instruction. They do not believe that success in the field of creative writing can be achieved with the approach of 'exploration or things that are not necessarily.' (Ansari et al, 2012: 112). Because of the above contention, then Ansari, et 
al trying to bridge differences over by bringing learning approach that can develop creativity as has been done by Lenning, et al (2013). Meanwhile, the study also refers to a study that was made by Moseley et al (2005a; 2005b) on the pedagogy of teaching in the field of creative writing.

In essence, related to the learning creative writing in the study Ansari, et al (2012: 114), called a few things that should be considered in developing a model of learning creative writing: (a) class creative writing should be a class that supports the development of learners regardless of background of learners such; (B) one of the ways to create learning environments that support is through collaborative learning; (C) for creative writing is an activity that accommodates variation or difference, then there should be plenty of options for learning activities; (D) the learning process should be able to accommodate a higher level of thinking (high order thinking); (E) an integrated learning process where the learner should be able to associate creative writing with other subjects.

In general, according to Mansoor (2010: 202-203), there are three major groups of problems in creative writing in a foreign language:

a. Linguistics. This involves difficulties with grammar and vocabulary as well as interference with the first language to writing in English.

b. Affective. Due to language problems above, students feel fear / anxiety will score rendang so creative writing becomes a burden or problem.

c. Creative writing their perception that it is the inborn ability (talent) so it can not be learned.

When viewed closely, then the difficulty of linguistic and affective interlinked and pose a dilemma as the problems faced by learners of English in the EFL context analogous to Writing Anxiety felt by learners in writing ability. In fact, according to Mansoor (2010: 206) considers creative writing students can not be separated from the grammar and vocabulary is good and right opposite to the existing definition of the creative writing. Based on the definition that has been made then the Ministry of Commerce split into fourteen creative industry sector (14), namely: advertising, architecture, art goods market, craft, design, fashion, video, films, and photography, interactive game, music, performing Arts, Publishing and printing, computer services and software, television and radio, research and development.

Research and development is a creative activity related to innovative businesses that offer discovery science and technology and the application of science and knowledge for product improvement and creation of new products, new processes, new materials, new tools, new methods, and new technologies that can meet the needs of market; including those related to the humanities such as research and development of language, literature and art, as well as business and management consulting services.

By this it can be concluded that the creative industries have the potential resource is not limited because the dasarknya creativity are the basic elements of a person, so that every human being has the potential for doing business in this industry. The role of academics in the development of creative industries is clearly visible from the Tri Darma Higher Education:

1. The role of education is intended to encourage the birth of creative generation of Indonesia with the mindset that supports the growth initiative and work in the creative industries;

2. The role of research carried out to provide input on the model of creative industry development policies and instruments needed and produce technologies that support the operations and the efficient use of resources and makes national competitive creative industries;

3. The role of community service performed to form a community with other institutions 
that support the flourishing of national creative industries

From exposure to Tri Darma Higher Education this, it should be academics in preparing courses despite ensure each courses allow the student or learner's competence in the field of creative industries. In terms of lecturers, this will provide new ideas for research and development as well as community service. As for the students it will make them feel and know the relevance of the courses they are studying with the world of work. So that it would increase the motivation and enrich their learning experience.

\section{Method}

The method used for this research was R \& D (Research and Development). The population of this study was a number of students who have studied Introduction to Literature course at English Language Study Program, English Department, Faculty of Languages and Arts, Universitas Negeri Padang. The sample were students who have studied course of Children Literature in 2018. The participants of this study were 28 students who were registered in the fourth year. The participants consisted of students of Department of English Language and Literature who has taken courses Children Literature in 2017. The quantitative data were obtained from the questionnaire and they were analyzed in quantitative or statistical calculations. Besides the data were analyzed descriptively.

\section{Finding and Discussion}

\subsection{Students' Problems in Understanding Explanations of Concepts and Examples of Children Literature}

Table 1. Scores of Respondents' Responses to Problems in Understanding Explanations of Concepts and Examples of Children Literature

\begin{tabular}{clc} 
No & \multicolumn{1}{c}{ Statements } & Score \\
\hline 1 & Definitions of Children Literature & 2,68 \\
2 & History of Children Literature & 3,24 \\
3 & Literature Usefulness of studying Children Literature & 3 \\
4 & $\begin{array}{l}\text { Elements of Children Literature (prose / stories): plot, } \\
\text { character, setting, theme }\end{array}$ & 2,96 \\
5 & Genre Children Literature (Fairy Tale, Folk Tale, Myth, & 3,08 \\
& Legend, Epic and Fable) & 3,32 \\
6 & Analyzing Children Literature (prose) & 3,28 \\
7 & Analyzing Children Literature (poetry) & 3,28 \\
8 & Analyzing Children Literature (play script) & 5 \\
9 & Characteristics of Children Literature that differentiate with & \\
\hline
\end{tabular}

Based on the table above, in general, the values obtained for each statement, regarding the respondent's response to the problem in understanding the concept explanation and the Children Literature example, varied from 2.68 to 5 , which means that the highest value is 5 and the lowest value is 2.68. In this case, the statement with the highest score is "the 
characteristics of Children Literature that distinguishes it from other genres". This means that respondents always experience problems when learning the characteristics of Children Literature that distinguishes from other genres.Furthermore, the second highest statement is found in number 6 with a value of 3,32 while the statement that gets the other high scores are the statements number 7 and 8 which have the same value, that is 3.2. It means that respondents sometimes experience problems in understanding the explanation of analyzing Children Literature (process, poetry, and play script).

From the table above it can be concluded that there are four problems to be considered more seriously in understanding the explanation of concepts and examples of Children Literature. These problems are (1) characteristics of Children 's Literature that distinguishes from other genres; (2) analyzing Children Literature (process); (3) analyzing Children Literature (poetry); and (4) analyzing Children Literature (play script).

\subsection{Students' Responses to Problems in Doing the Exercises and Aassignments of Children's Literature}

Table 2. Score Responses of Respondents to Problems in Doing Exercises and Assignments of Children

\begin{tabular}{clc} 
No & \multicolumn{1}{c}{$\begin{array}{c}\text { Literature } \\
\text { Statements }\end{array}$} & Score \\
\hline 1 & Definition of Children Literature & 2,76 \\
2 & History of Children Literature & 3,24 \\
3 & Usefulness of studying Children Literature & 2,88 \\
4 & Elements of Children Literature (prose / stories): plot, & 3,04 \\
& character, setting, theme & 3,24 \\
5 & Genre Children Literature (Fairy Tale, Folk Tale, Myth, & \\
& Legend, Epic and Fable) & 3,48 \\
6 & Analyzing Children Literature (prose) & 3,48 \\
7 & Analyzing Children Literature (poetry) & 3,48 \\
8 & Analyzing Children Literature (play script) & 5 \\
9 & Characteristics of Children Literature differentiate with other & \\
\hline & genres & \\
\hline
\end{tabular}

In general, the values obtained for each statement, regarding the respondent's response to the problem in doing the exercises and the tasks of Children Literature, varied from 2.76 to 5 , which means that the highest value is 5 and the lowest value is 2.76 . In this case the statement with the highest score is "the characteristics of Children Literature that distinguishes it from other genres". This means that respondents always experience problems when doing the exercises and the tasks of Children Literature which are related to the characteristics of Children Literature that distinguishes from other genres.

Furthermore, the second highest statement is found in numbers 6, 7, and 8 with the same value that is 3.48. This means that respondents sometimes experience problems when doing exercises and the tasks of Children Literature which relate to analyzing Children Literature (process, poetry, and play script).

From the table above, it can be concluded that the problem below is important to consider in doing the exercises and the Children Literature. These problems are (1) characteristics / characteristics of Children Literature that distinguishes from other genres; (2) analyzing 
Children Literature (process); (3) analyzing Children Literature (poetry); and (4) analyzing Children Literature (play script).

\subsection{Problems Most Students Experienced}

Tabel 3. Percentage of Number of Respondents Experiencing Problems in Learning Subjects of Children Literature

\begin{tabular}{|c|c|c|c|}
\hline No & Statements & $\begin{array}{c}\text { Respon } \\
\text { dent }\end{array}$ & $\begin{array}{c}\text { Percen } \\
\text { tage }\end{array}$ \\
\hline 1 & $\begin{array}{l}\text { I have difficulty understanding Children Literature course } \\
\text { because of the complexity of the language used. }\end{array}$ & 9 & 40 \\
\hline 2 & $\begin{array}{l}\text { I have difficulty understanding my Children Literature course } \\
\text { because of the rambling presentation. }\end{array}$ & 14 & 84 \\
\hline 3 & $\begin{array}{l}\text { I have difficulty understanding my Children Literature course } \\
\text { because I do not have enough knowledge base. }\end{array}$ & 8 & 48 \\
\hline 4 & $\begin{array}{l}\text { I have difficulty understanding the course of Children } \\
\text { Literature because of its incomplete presentation. }\end{array}$ & 14 & 84 \\
\hline 5 & $\begin{array}{l}\text { I have difficulty understanding the course of Children } \\
\text { Literature because it is not accompanied by examples that are } \\
\text { easy to understand. }\end{array}$ & 11 & 68 \\
\hline 6 & $\begin{array}{l}\text { I have difficulty understanding the course of Children 's } \\
\text { Literature because the presentation is not accompanied by } \\
\text { illustrations or charts. }\end{array}$ & 10 & 60 \\
\hline 7 & $\begin{array}{l}\text { I have difficulty understanding the course of Children } \\
\text { Literature because the presentation uses multimedia media. }\end{array}$ & 9 & 48 \\
\hline 8 & $\begin{array}{l}\text { I have difficulties in doing the assignments or training in } \\
\text { Children 's Literature courses because of the complexity of the } \\
\text { language used in the exercise. }\end{array}$ & 15 & 88 \\
\hline 9 & $\begin{array}{l}\text { I have difficulty working on assignments or training in } \\
\text { Children Literature courses because they do not match the } \\
\text { explanations and examples given. }\end{array}$ & 9 & 52 \\
\hline 10 & $\begin{array}{l}\text { I have difficulty working on assignments or training in Children } \\
\text { 's Literature courses because they are not accompanied by } \\
\text { examples of how to do the exercises. }\end{array}$ & 7 & 36 \\
\hline
\end{tabular}

Based on the table above, in general each respondent's answer to the problems that are often experienced varies from statement 1 to statement 10. From all the statements above, the most frequent problems experienced by respondents are in statement number 8 , namely "I have difficulty working on assignments or training in Children Literature courses because of the complexity of the language used in the exercise ". This is evidenced by the number of respondents who voted for the statement, namely 15 respondents (88\%). Furthermore, the second highest problem experienced by respondents is in numbers 2 and 4 . This is evidenced by the number of respondents who voted for the statement, amounting to 14 respondents $(84 \%)$. 
Meanwhile, the least experienced problems for respondents were in statement number 10, namely "I have difficulty in carrying out assignments or training in Children 's Literature courses because they are not accompanied by examples of how to do the exercises". This can be seen from the small number chosen by respondents from all statements, namely 7 respondents $(36 \%)$.

\subsection{Students' Responses to the Importance of Various Topics in the Course of Children Literature}

Table 4 Score Responses of Respondentst to the Importance of Various Topics in The Course of Children 'S Literature

\begin{tabular}{llc}
\hline No & \multicolumn{1}{c}{ Statements } & Scores \\
\hline 1 & Definition of Children Literature & 4,64 \\
\hline 2 & History of Children Literature & 4,6 \\
\hline 3 & Usefulness of studying Children Literature & 4,52 \\
\hline 4 & Elements of Children Literature (plot, character, setting, theme) & 4,72 \\
\hline 5 & $\begin{array}{l}\text { Genre Children Literature (Fairy Tale, Folk Tale, Myth, Legend, Epic } \\
\text { and Fable) }\end{array}$ & 4,76 \\
\hline 6 & Analyzing Children Literature (prose) & 4,8 \\
\hline 7 & Analyzing Children Literature (poetry) & 4,6 \\
\hline 8 & Analyzing Children Literature (play script) & 4,52 \\
\hline 9 & The reading strategy of Literature written in English & 4,48 \\
\hline 10 & How to read Children Literature & 4,64 \\
\hline 11 & Children in ideology & 4,56 \\
\hline 12 & Children Literature in ideology & 4,64 \\
\hline 13 & Children Literature and the literary repertoire & 4,72 \\
\hline 14 & Reading, discussing, and interpreting Children Literature & 4,6 \\
\hline 15 & Literary criticism and Children Literature & 4,52 \\
\hline 16 & Looking at the basic elements of Children Literature & 4,4 \\
\hline 17 & Rhetorical style in Children Literature & 4,6 \\
\hline 18 & Understanding utopian worlds in Children Literature & 4,48 \\
\hline 19 & Realism and moral attitudes in Children Literature & 4,56 \\
\hline 20 & Poetic language and literary style & 4,76 \\
\hline 21 & Reader response in Children Literature: listening to determine audience & 4,96 \\
\hline 22 & Adult and children interpreting Children Literature together & 4,96 \\
\hline 23 & How to write creative writing (processes such as innovative fairy tales / & 4,96 \\
& innovative folktales / short stories / etc) after learning to interpret Children & \\
\hline & Literature (prose / stories). & \\
\hline & &
\end{tabular}


24 How to write creative writing (poetry such as poetry for children / bio 5 poetry) after learning to interpret Children 's Literature (poetry for children)

25 How to write creative writing (play script) after learning to interpret 5 Children 's Literature (play script)

26 Exercise / task of creating writing (poetry) inspired by children's poetry 5 discussed in class

27 Exercise / task of creating writing (poetry) inspired by children's poetry 5 read outside the classroom

28 The exercise / task of creating writing (prose) that is inspired by children's 5 prose discussed in class.

29 The exercise / task of creating writing (process) which is inspired by 5 children's prose that is read outside the classroom.

30 Exercise / assignments to create creating writing (play script) that are 5 inspired by children's drama scripts discussed in class or read in class.

31 Exercise / task of creating writing (play script) inspired by children's 5 drama script that has been read outside the classroom.

32 Exercises / assignments to create creating writing (in any form) inspired 5 by the results of interpretation or analysis of various texts of Children Literature that have been read and studied in written or printed form (hardcopy).

33 The exercise / assignment given is in the form of creating writing (in any 5 form) which is inspired by the results of the interpretation or analysis of various texts of Children Literature that have been read and studied in digital form (online).

34 The exercises / assignments given are in the form of creating writing (in 5 the form of writing: process, poetry, play script) which is inspired by the results of the interpretation or analysis of various texts of Children Literature that has been read and studied.

35 The exercise / assignment given is in the form of creating writing (in the 5 form of digital storytelling) which is inspired by the results of interpretation or analysis of various texts of Children Literature that have been read and studied.

In general, the values obtained for each statement regarding the respondent's response to the importance of various topics in the Children Literature course, varied from 4.4 to 5, which means that the highest score is 5 and the lowest value is 4.4. In this case the highest value statement is number 24 to 35 . Furthermore, the second highest statement is found at numbers 21,22 , and 23 with the same value of 4.96 . From the table above it can be concluded that almost all of the above topics are important for the course of Children Literature. From the various topics above, there are several topics that are very important in the subjects of 
Children Literature. The topics are (1) how to write creative writing (poetry such as poetry for children / bio poetry) after learning to interpret Children Literature (poetry for children); (2) exercise / task of creating writing (poetry) inspired by children's poetry discussed in class;

(3) exercise / task of creating writing (poetry) inspired by children's poetry discussed in class; (4) exercise / task to create creating writing (poetry) inspired by children's poetry read outside the classroom; and (5) exercise / task of creating writing (prose) that is inspired by children's prose discussed in class.

\subsection{Students' Responses to the Importance of Diverse Exercises and Tasks}

Table 5 Score Respondents' Responses to the Importance of Diverse Exercises and Tasks

\begin{tabular}{clc}
\hline No & \multicolumn{1}{c}{ Statements } & Scores \\
\hline 1 & Definition of Children Literature & 4,56 \\
\hline 2 & History of Children Literature & 4,6 \\
\hline 3 & Usefulness studying of Children Literature & 4,52 \\
\hline 4 & Elements of Children Literature (plot, character, setting, theme) & 4,76 \\
\hline 5 & Genre Children Literature (Fairy Tale, Folk Tale, Myth, Legend, Epic and & 4,64 \\
& Fable) & \\
\hline 6 & Analyzing of Children Literature (prose) & 4,8 \\
\hline 7 & Analyzing of Children Literature (poetry) & 4,72 \\
\hline 8 & Analyzing of Children Literature (play script) & 4,64 \\
\hline 9 & Reading strategy of Children Literature written in English & 4,4 \\
\hline 10 & How to read Children Literature & 4,68 \\
\hline 11 & Children in ideology & 4,56 \\
\hline 12 & Children Literature in ideology & 4,68 \\
\hline 13 & Children Literature and the literary repertoire & 4,64 \\
\hline 14 & Reading, discussing, and interpreting Children Literature & 4,56 \\
\hline 15 & Literary criticism and Children Literature & 4,32 \\
\hline 16 & Looking at the basic elements of Children Literature & 4,6 \\
\hline 17 & Looking at the basic elements of Children Literature & 4,68 \\
\hline 18 & Understanding utopian worlds in Children Literature & 4,48 \\
\hline 19 & Realism and moral attitudes in Children Literature & 4,36 \\
\hline 20 & Realism and moral attitudes in Children Literature & 4,56 \\
\hline 21 & Reader response in Children Literature: listening to determine audience & 4,92 \\
\hline 22 & Adult and children interpreting Children Literature together & 4,84 \\
\hline 23 & $\begin{array}{l}\text { Style of writing creative writing (prose like innovative fairy tales/ innovative } \\
\text { folktales/ short stories/etc) after learning how to interpret Children Literature } \\
\text { (prose/ stories). }\end{array}$ & 4,92 \\
\hline 24 & $\begin{array}{l}\text { Style of writing creative writing (poetry like poetry for children/ bio poetry) } \\
\text { after learning how to interpret Children Literature (poetry for children) }\end{array}$ & 4,92 \\
\hline 25 & $\begin{array}{l}\text { Style of writing creative writing (play script) after learning how to interpret } \\
\end{array}$ & 4,92 \\
\hline & Children Literature (play script) & \\
\hline
\end{tabular}

In general, the values obtained for each statement regarding the respondent's response to the importance of various exercises and tasks vary from 4.32 to 4.92 , which mean that the 
highest value is 4.92 and the lowest value is 4.32 . In this case the statement with the highest score is statements number 21, 23, 24, and 25. Furthermore, the second highest statement is found at number 22 with a value of 4.84 . From the table above, it can be concluded that almost all of the above topics are important for doing the exercises and assignments for the Children Literature. From the various topics above, there are several topics that are very important in doing the exercises and the assignments of the Children Literature. The topics are (1) reader response in Children Literature: listening to determine audience (Reader response in Children Literature: listening to determine audience); (2) how to write creative writing (processes such as innovative fairy tales / innovative folktales / short stories / etc) after learning to interpret Children Literature (prose / stories); (3) how to write creative writing (poetry such as poetry for children / bio poetry) after learning to interpret Children 's Literature (poetry for children); (4) How to write creative writing (play script) after learning to interpret Children 's Literature (play script); and (5) Adult and children interpreting Children Literature together (Adults and children interpret Children Literature).

\subsection{Students' Responses to Topics Related to Creative Writing and Children Literature}

Table 6 Respondents' Responses to Topics Related to Creative Writing and Children Literature

\begin{tabular}{|c|c|c|}
\hline No & Statements & Scores \\
\hline 1 & Children's poetry & 4,68 \\
\hline 2 & Children's drama & 4,72 \\
\hline 3 & Children's film and televise script & 4,56 \\
\hline 4 & Children's film and televise script & 4,72 \\
\hline 5 & Kids' song & 4,88 \\
\hline 6 & Kids'speech & 4,2 \\
\hline 7 & Children's biography & 4,24 \\
\hline 8 & Children's diary & 4,36 \\
\hline 9 & Children's dialogue journal & 4,4 \\
\hline 10 & Children's letter & 4,12 \\
\hline 11 & Children's letter & 4,24 \\
\hline 12 & Children's Vignettes & 4,24 \\
\hline 13 & Children's wall magazine & 4,44 \\
\hline
\end{tabular}

In general, the values obtained for each statement, regarding the respondent's response to the topic related to Creative Writing and Children Literature, varied from 4.12 to 4.88 , which means that the highest value is 4.88 and the lowest value is 4, 12 In this case the highest value statement is number 5 . Next, the second highest statement is in numbers 2 and 4 with the same value of 4.72 .

From the table above it can be concluded that almost all of the above topics are important because they are related to creative writing and Children Literature. From the various topics above, there are some very important topics related to creative writing and children literature. The topics are children's song, children's television films and scripts, children's drama, and children's poetry 


\subsection{Students' Need to the Media of Learning Creative Writing-Based Children Literature Course}

Table 7 Respondents' Responses to the Need of Need to the Media of Learning Creative WritingBased Children Literature Course

\begin{tabular}{|c|c|c|}
\hline No & Statements & Scores \\
\hline 1 & Teaching material delivered in writing & 4,6 \\
\hline 2 & Teaching material delivered in the form of audio recordings & 4,36 \\
\hline 3 & $\begin{array}{l}\text { Teaching materials are delivered digitally in the form of power point } \\
\text { presentations }\end{array}$ & 4,8 \\
\hline 4 & Teaching material delivered in audio-visual form & 4,68 \\
\hline 5 & $\begin{array}{l}\text { Teaching materials that are delivered digitally in the form of interactive } \\
\text { multimedia-based teaching materials, such as e-learning, game applications }\end{array}$ & 4,48 \\
\hline 6 & Training / assignments given in writing & 4,48 \\
\hline 7 & Exercises / assignments delivered in the form of audio recordings & 4,4 \\
\hline 8 & $\begin{array}{l}\text { Exercises / tasks that are delivered digitally in the form of power point } \\
\text { presentations }\end{array}$ & 4,64 \\
\hline 9 & Exercises / assignments delivered in audio-visual form & 4,48 \\
\hline 10 & $\begin{array}{l}\text { Exercises / tasks that are delivered digitally in the form of interactive } \\
\text { multimedia-based teaching materials. }\end{array}$ & 4,52 \\
\hline 11 & $\begin{array}{l}\text { The training / task given is in the form of creating writing (poetry) which is } \\
\text { inspired by children's poetry that is discussed in class or read in and out of } \\
\text { class in hardcopy. }\end{array}$ & 5 \\
\hline 12 & $\begin{array}{l}\text { The training / assignment given is in the form of creating writing (poetry) } \\
\text { which is inspired by children's poetry that is discussed in class or read in } \\
\text { and out of class in the form of softcopy. }\end{array}$ & 5 \\
\hline 13 & $\begin{array}{l}\text { The training / assignment given is in the form of creating writing (process) } \\
\text { which is inspired by children's prose that is discussed in class or read in and } \\
\text { out of class in hardcopy. }\end{array}$ & 5 \\
\hline 14 & $\begin{array}{l}\text { The training / assignment given is in the form of creating writing (process) } \\
\text { which is inspired by children's prose which is discussed in class or read in } \\
\text { and out of class in the form of softcopy. }\end{array}$ & 5 \\
\hline 15 & $\begin{array}{l}\text { The training / assignment given is in the form of creating writing (play } \\
\text { script) which is inspired by the children's drama script that is discussed in } \\
\text { class or read in and out of class in hardcopy. }\end{array}$ & 5 \\
\hline 16 & $\begin{array}{l}\text { The training / assignment given is in the form of creating writing (play } \\
\text { script) which is inspired by the children's drama scripts discussed in class or } \\
\text { read in and out of class in the form of softcopy. }\end{array}$ & 5 \\
\hline 17 & $\begin{array}{l}\text { The training / assignment given is in the form of creating writing (in any } \\
\text { form) which is inspired by the results of the interpretation or analysis of } \\
\text { various texts of Children Literature that have been read and studied in } \\
\text { hardcopy. }\end{array}$ & 5 \\
\hline
\end{tabular}


18 The training / assignment given is in the form of creating writing (in any form) which is inspired by the results of the interpretation or analysis of various texts of Children Literature that have been read and studied in the form of softcopy.

19 The training / assignment given in the form of creating writing (in the form of writing) inspired by the results of interpretation or analysis of various texts of Children Literature that has been read and studied.

20 The training / assignment given is in the form of creating writing (in the form of digital storytelling) which is inspired by the results of interpretation or analysis of various texts of Children Literature that have been read and studied.

In general, the values obtained for each statement, regarding the respondent's response to the type of media used, varied from 4.36 to 5 , which means that the highest value is 5 and the lowest value is 4.36. In this case the highest value statement is number 11-20. Furthermore, the second highest statement is found at number 3 with a value of 4.8.

From the table above, it can be concluded that almost all of the above media are important to the subjects of the Children Literature. From the various media above, there are several very important media related to creative writing and children literature. The media are soft copy, hard copy, writing, digital storytelling, power point.

\section{Conclusion}

In developing course of creative writing -based Children Literature for EFL college students, the lecturers need to pay attention on (1) the way to analyze prose for children, poetry for children, play script for children; the way to create or produce prose for children, poetry for children, play script for children; (3) various and interesting tasks and exercises of creative writing in Children Literature; and (4) various media to support teaching and learning creative writing -based Children Literature course.

Since this study was the first step of Research and Development and it is still limited on the students' need analyzes based the students' responses. Interview with students and lecturers of literary studies; and creating teaching-learning materials which are suitable with the students' need are necessary for further research. 


\section{References}

Appleyard, J.A. (1961). Becoming a Reader: The Experience of Fiction from Childhood to Adulthood. London: Harvard University Press.

Azarnoosh, Maryam, Mitra, Zeraatpishe, Akram, Faravani, and Hamid, Reza Kargozari. (2016). Issues in Materials Development. Melbourne: Sense Publishers.

Beck, Heather. (2012). Teaching Creative Writing. New York: Palgrave Macmillan.

Belawati, Tian. (2003). Pengembangan Bahan Ajar. Jakarta: Pusat Penerbitan Universitas Terbuka.

Bottighmier, R. B. (1998). An Important System of Its Own: Defining Children Literature." Princeton University Chronicle, 2, 190-210.

Carr. J. (2009). Creative Industries, Creative Workers, and the Creative Economy: a Review of Selected Recent Literature. Edinburg: Queens Printers of Scottland.

Cunningworth, A. (1995). Choosing your Coursebook. Oxford: Heinemann.

Departemen Perdagangan RI. (2008). Pengembangan Ekonomi Kreatif Indonesia 2025 Rencana Pengembangan Ekonomi Kreatif Indonesia 2009-2015. Jakarta: Departemen Perdagangan.

Departemen Pendidikan Nasional. (2008). Panduan Pengembangan Bahan Ajar. Jakarta: Departemen Pendidikan Nasional.

Disher, Garry. (2001). Writing Fiction. Melbourne: McPherson's Printing Group.

Earnshawn, Steven. (2007). The Hand Book of Creative Writing. Edinburgh: Edinburgh University Press Ltd.

Graves, Katheleen. (2000). "Developing materials". Designing Language Course: a Guide for Teachers. Boston: Cengage Learning. pp. 149-171.

Hillman, J. (1999). Discovering Children Literature (2nd ed.). Upper Saddle River, NJ: Merrill.

Howkins, J. (2002). The Creative Economy: How People Make Money from Ideas. New York: Clay Ltd.

Howard, J. and Major, J. (2005) Guidelines for Designing Effective English Language Teaching Materials. Seoul, South Korea: PAAL9, Oct 2004. In Proceedings of the 9th 33 Conference of Pan-Pacific Association of Applied Linguistics 101-109. (Online). http://www.paaljapan.org/resources/ proceedings/PAAL9/pdf/Howard.pdf. Retrieved in 1 April 2019.

Hunt, Peter. (1999). Understanding Childrens' Literature. London: Routledge.

Jacobs, Heidi Hayes.(2015). Curriculum 21: Essential Education for a Changing World. New York: London: Routledge.

Lesnik-Oberstein, K. (1996). Defining Children Literature and childhood. In P. Hunt (Ed.), International Companion Encyclopedia of Children Literature (pp. 17- 31). London: Routledge.

Lukens, Rebecca J. (1995). A Critical Handbook of Children Literature. New York: HarperCollins.

Lukens, Rebecca J. (2007). Children Literature. Boston: Pearson Education, Inc.

Mbulu, J. (2004). Pengembangan Bahan Ajar. Malang: Elang Mas.

Miils, Paul. (2006). The Routledge Creative Writing Coursebook. London: Routledge. 
Mishan, Freda and Ivor, Timmis. (2015). Materials Development for TESOL. Edinburgh: Edinburgh University Press.

Morley, David. (2007). The Cambridge Introduction to Creative writing. India: Cambridge University Press.

Panen, Paulina dan Purwanto. (2006). Penulisan Bahan Ajar. Jakarta: PAU-PPAI-UT.

P. May, Jill. (1995). Children Literature and Critical Theory. NewYork: Oxford University Press.

Pratowo, Andi. (2001). Jenis dan Bentuk Bentuk Sumber Belajar dan Bahan Ajar. PowerPoint Slide Shows. Yogyakarta: Program Studi Pendidikan Guru MI Fakultas Tarbiyah, UIN Sunan Kalijaga.

Showalter, E. (2010). Teaching Literature. Singapore: Blackwell Publishing.

Sugiyono. (2013). Metode Penelitian Kuantitatif Kualititatif dan R\&D. Bandung: Alfabeta.

Sujadi, (2003). Metodologi Penelitian Pendidikan. Jakarta. Rineka Cipta.

Simatupang, Togar M. 2010. Perkembangan Industri Kreatif. (Online) http://www.cs.unsyiah.ac.id/ frdaus/PenelusuranInformasi/File-Pdf/ perkembangan ind kreatif.pdf. Retrieved on 12 Januari 2019.

Tomlison. 1998. (e.d.) Materials Development in Language Teaching. Cambridge:Cambridge University Press.

Tomlinson, C. M., \& Lynch-Brown, C. (2002). Essentials of Children Literature. Boston:Allyn and Bacon.

-------- 2012. "Materials Development for Language Learning and Teaching". Language Teaching Cambridge Journal. Vol. 45, No. 2, pp. 143-179.

2007. “Introduction: Are Materials Developing?". In B. Tomlinson. Developing Materials for Language Teaching. pp. New York: Continuum. pp. 1-11. 